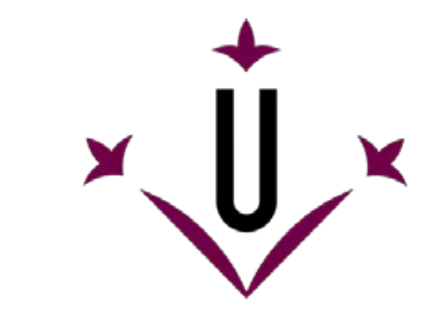

Universitat de Lleida

Document downloaded from:

http://hdl.handle.net/10459.1/65022

The final publication is available at:

https://doi.org/10.1111/j.1466-8238.2010.00550.x

Copyright

(c) Blackwell Publishing Ltd, 2010 


\section{Land-use changes as major drivers of Mountain pine (Pinus uncinata Ram.) expansion in the Pyrenees}

Running header: Land-use changes drive Pinus uncinata expansion

Authors: Aitor Améztegui, Lluís Brotons and Lluís Coll

Institution: Forest Technology Centre of Catalonia.

Ctra. Sant Llorenç de Morunys, km.2

E- 25280 Solsona, Spain

\section{Contact details:}

Corresponding Author: Aitor Améztegui

e-mail: aitor.ameztegui@ctfc.cat, tel.+34 973481 752, fax. +34 973480431 
Post-print version. The final version of this article can be found at: Ameztegui A, Brotons L, Coll L. (2010) Land-use changes as major drivers of Mountain pine (Pinus uncinata Ram.) expansion in the Pyrenees. Global Ecology and Biogeography 19 (5): 632-641. DOI: $10.1111 / \mathrm{j} .1466-8238.2010 .00550 . x$

\section{ABSTRACT}

Aim To assess the spatial patterns of forest expansion (encroachment and densification) for Mountain pine (Pinus uncinata Ram.) during the last 50 years in a whole mountain-range scale by the study of different topographic and socio-economic potential drivers in the current globalchange context.

Location The study area includes the whole distributional area of Mountain pine in the Catalan Pyrenees (NE Spain). This represents more than 80 municipalities, covering a total area of 6,018 $\mathrm{km}^{2}$.

Methods Forest cover was obtained by image reclassification of more than 200 pairs of aerial photographs taken in 1956 and 2006. Encroachment and densification were determined according to changes in forest cover, and were expressed as binary variables on a $150 \times 150 \mathrm{~m}$ cell-size grid. We then used logistic regression to analyze the effects of several topographic and socio-economic variables on forest expansion.

Results In the period analyzed, Mountain pine increased its surface coverage by 8,898 hectares (an increase of more than 16\%). Mean canopy cover rose from $31.0 \%$ in 1956 to $55.6 \%$ in 2006. Most of the expansion was found on north-facing slopes and at low altitudes. Socio-economic factors arose as major factors of Mountain pine expansion, as encroachment rates were higher at municipalities with greater population losses or weaker primary sector development.

Main Conclusions The spatial patterns of Mountain pine expansion highly matched the main patterns of land-use change in the Pyrenees, suggesting that land-use changes have played a more determinant role than climate in driving forest dynamics at landscape scale over the period 
Post-print version. The final version of this article can be found at:

Ameztegui A, Brotons L, Coll L. (2010) Land-use changes as major drivers of Mountain pine (Pinus uncinata Ram.) expansion in the Pyrenees. Global Ecology and Biogeography 19 (5): 632-641.

DOI: 10.1111/j.1466-8238.2010.00550.x

studied. Further studies on forest expansion at regional scale should incorporate patterns of land-use changes to correctly interpret drivers of forest encroachment and densification.

Keywords Mountain pine, Pyrenees, encroachment, densification, land-use changes, global warming, canopy cover, image reclassification 
Post-print version. The final version of this article can be found at: Ameztegui A, Brotons L, Coll L. (2010) Land-use changes as major drivers of Mountain pine (Pinus uncinata Ram.) expansion in the Pyrenees. Global Ecology and Biogeography 19 (5): 632-641. DOI: $10.1111 / \mathrm{j} .1466-8238.2010 .00550 . x$

\section{INTRODUCTION}

2 Despite the high rates of deforestation measured worldwide, forest cover in most developed 3 countries is on the increase (Coop \& Givnish, 2007; Gellrich et al., 2007a; Gellrich \&

4 Zimmermann, 2007). Although this increase is mainly caused by forest encroachment into open

5 areas, there has also been an increase in canopy cover of pre-existent forests, either through

6 enhanced growth of pre-existent individuals or the recruitment of new ones (densification)

7 (Poyatos et al., 2003; Gehrig-Fasel et al., 2007). Forest expansion (including both encroachment and densification) does not occur homogenously at the local scale, as it is determined by both natural and cultural factors, such as local recent livestock pressure (Dirnböck et al., 2003; Lasanta-Martinez et al., 2005; Coop \& Givnish, 2007), topographic factors (Poyatos et al., 2003; Gellrich \& Zimmermann, 2007) and locally dominant ecological and socio-economic conditions, among others (Debussche et al., 1999). However, these drivers usually act at different scales: for example, the decision to abandon a farmland depends on socio-economic factors, and subsequent changes in land cover will be modulated by ecological processes, which in turn are associated with environmental and climatic conditions (Rutherford et al., 2008). Therefore, researchers have studied land-cover change at a wide range of spatial scales, from small plots to entire mountain ranges. Local-scale approaches based on the study of plots usually employ dendrochronology methods (Camarero \& Gutierrez, 2007; Chauchard et al., 2007), while at larger spatial scales, land-cover changes have mainly been assessed by comparison of aerial photographs (Miller, 1999; Coop \& Givnish, 2007; Gellrich et al., 2008). Lastly, changes in large areas (covering thousands of square kilometres) have mainly been analyzed using remote sensing techniques (Gellrich \& Zimmermann, 2007; Millington et al., 2007). Although attempts have been made to integrate these scales (Jump et al., 2006; Lasanta \& Vicente-Serrano, 2007; Gellrich et al., 2008; Rutherford et al., 2008), this is still one of the 
Post-print version. The final version of this article can be found at:

Ameztegui A, Brotons L, Coll L. (2010) Land-use changes as major drivers of Mountain pine (Pinus uncinata Ram.) expansion in the Pyrenees. Global Ecology and Biogeography 19 (5): 632-641. DOI: $10.1111 / \mathrm{j} .1466-8238.2010 .00550 . x$

1 major challenges facing the study of forest expansion, since a holistic view is required in order

2 to better understand the drivers underlying these processes.

3 Many European mountain areas have recorded a significant increase in temperatures since the

4 1940s (Diaz \& Bradley, 1997). Mountain ecosystems, especially areas located at high altitude,

5 are considered particularly vulnerable to climate change (Dirnböck et al., 2003; Camarero et al.,

6 2006). Forest encroachment in these systems has often been attributed to global warming, which

7 may favour conditions for tree recruitment and growth near or beyond the tree line (Macdonald

8 et al., 1998; Peñuelas \& Boada, 2003; Camarero \& Gutierrez, 2004; Camarero et al., 2006;

9 Batllori \& Gutierrez, 2008). Nevertheless, over the last century, European mountain systems

10 have suffered not only global warming but also major demographic, economic and

11 organizational changes (Garcia-Ruiz et al., 1996; Hofgaard, 1997; Dirnböck et al., 2003).

12 Therefore, land-use changes must be considered as a major potential factor driving forest

expansion, especially in areas exposed to significant human influence, such as north-

Mediterranean basin (Dale, 1997; Sala et al., 2001; Chauchard et al., 2007; Gehrig-Fasel et al., 2007; Gellrich et al., 2007b; Millington et al., 2007).

In order to integrate the different scales at which forest expansion acts and segregate climate change from land-use change as drivers of forest expansion, we performed the analysis on Mountain pine (Pinus uncinata Ram.), a species that grows in the subalpine belt of the Central and Eastern Pyrenees, where it constitutes most of the tree lines. We employed a multi-scale approach comparing hundreds of pairs of aerial photographs. Though this technique is widely used for assessing forest encroachment (Poyatos et al., 2003; Coop \& Givnish, 2007; Gellrich et al., 2008), it has rarely been employed for regional-scale studies. Furthermore, the densification process has been extensively studied along the tree line from a dendro-ecological, climaterelated standpoint (Szeicz \& Macdonald, 1995; Macdonald et al., 1998; Camarero \& Gutierrez, 
Post-print version. The final version of this article can be found at:

Ameztegui A, Brotons L, Coll L. (2010) Land-use changes as major drivers of Mountain pine (Pinus uncinata Ram.) expansion in the Pyrenees. Global Ecology and Biogeography 19 (5): 632-641.

DOI: $10.1111 / \mathrm{j} .1466-8238.2010 .00550 . x$

1 2004; Batllori \& Gutierrez, 2008) but has never, to our knowledge, been quantified at landscape

2 scale, despite reports establishing its important role in land-cover change contexts (Poyatos et

3 al., 2003; Gehrig-Fasel et al., 2007; Lasanta \& Vicente-Serrano, 2007).

4 The main objectives of this study were (i) to assess spatial patterns of Mountain pine

5 encroachment and densification in the Eastern Pyrenees at both local and regional scale, and (ii)

6 to infer the main factors driving these processes. Our main hypothesis is that if climate change

7 is the main driver of Mountain pine expansion, encroachment and densification will be more

8 evident at high altitudes, near the tree line. In contrast, if the primary drivers are changes in

9 land-use, then spatial patterns of expansion should match reported spatial patterns of land-use

10 changes. 
Post-print version. The final version of this article can be found at:

Ameztegui A, Brotons L, Coll L. (2010) Land-use changes as major drivers of Mountain pine (Pinus uncinata Ram.) expansion in the Pyrenees. Global Ecology and Biogeography 19 (5): 632-641.

DOI: $10.1111 / \mathrm{j} .1466-8238.2010 .00550 . x$

1

\section{MATERIALS AND METHODS}

2

3

4

5

6

7

8

9

\section{Study area}

\section{Location and description of the study area} Pyrenean tree lines.

\section{PLEASE INSERT HERE FIGURE 1}

The Pyrenees is a mountain range that spreads from east to west along the French and Spanish border, with an extension of more than $50,000 \mathrm{~km}^{2}$. The study area is located southeast of the 6 axial zone of the range, and includes the 83 municipalities of Catalonia with current presence of Mountain pine, thus covering a total area of $6,018 \mathrm{~km}^{2}$ (Fig. 1). The abrupt terrain of the study area, with altitude ranging from 500 to more than $3,000 \mathrm{~m}$ a.s.1., in conjunction with the proximity of Mediterranean Sea creates significant climatic variation. Thus, the highest areas are representative of mountain climate (mean annual temperature below $3^{\circ} \mathrm{C}$, precipitation over $1400 \mathrm{~mm}$ ), while the valley bottoms present much temperate conditions (mean annual temperature over $12^{\circ} \mathrm{C}$, precipitations below $700 \mathrm{~mm}$ ), and show some traits of mediterraneity in the eastern zone. Vegetation is also strongly influenced by this double altitude-mediterraneity gradient. With valley bottoms supporting most conventional human activities, the montane belt (600-1600 m a.s.1.) is dominated by beech (Fagus sylvatica L.) and silver fir (Abies alba Mill.) in humid areas, while Scots pine (Pinus sylvestris L.) dominates the dryer ones. The Alpine belt (over $2300 \mathrm{~m}$ a.s.1.) is highly conditioned by cold temperatures and only supports herbaceous vegetation, while the subalpine belt (1600-2300 m a.s.1.) is dominated by Mountain pine (Pinus uncinata Ram.), which can grow in all kinds of soils and forms most of the central and eastern 
Post-print version. The final version of this article can be found at: Ameztegui A, Brotons L, Coll L. (2010) Land-use changes as major drivers of Mountain pine (Pinus uncinata Ram.) expansion in the Pyrenees. Global Ecology and Biogeography 19 (5): 632-641. DOI: $10.1111 / \mathrm{j} .1466-8238.2010 .00550 . x$

$1 \quad$ Climatic and land-use changes in the Pyrenees

2 Over the last 50 years, the Pyrenees have gone through major changes in land-organisation

3 (Garcia-Ruiz, 1988; Garcia-Ruiz \& Lasanta, 1990). Until the mid-20th century, all the resources

4 needed by local societies had to be obtained locally, and thus landscapes were highly influenced

5 by human activities (Lasanta, 2002; Lasanta \& Vicente-Serrano, 2007). Since then, strong

6 depopulation trends in rural areas led to many farmlands being abandoned, while the crisis

7 affecting the transhumance system led to a sharp decline in livestock (Garcia-Ruiz, 1988;

8 Domínguez, 2001). Therefore, human-driven pressure concentrated on the most productive

9 areas, especially valley bottoms, while the hillslopes were exposed to high risk of abandonment

10 (Garcia-Ruiz, 1988; Garcia-Ruiz \& Lasanta, 1990). Along with these land-use changes, climate

11 in the Pyrenees has also changed during the last century, with annual mean temperature and annual mean minimum temperature increasing by $0.83^{\circ} \mathrm{C}$ and $2.11^{\circ} \mathrm{C}$, respectively (Bucher \& Dessens, 1991). These temperature increases are similar to those measured in other European mountain ranges, including the Alps (Dirnböck et al., 2003).

\section{Data preparation and determination of forest cover}

16 To investigate changes in Mountain pine distribution and canopy cover, we conducted a GIS

17 analysis by comparing more than 200 pairs of aerial photographs taken in 1956 and 2006 and

18 covering the whole surface of the study area. The 1956, grey-scale photographs (with a

19 resolution of $1 \mathrm{~m}$ )) were geo-referenced and orthorectified. For each 1956 photo, at least 15

20 ground control points were identified, and a digital elevation model (DEM) was added in order

21 to incorporate altitude coordinates. Each 1956 and 2006 image was semi-automatically

22 reclassified into a binary raster with 'tree' and 'non-tree' values, and with a resolution of 1

23 meter (Fig. 2), and all the 1956 and 2006 reclassified images were stitched into mosaics. A

$24150 \times 150 \mathrm{~m}$ sampling grid was created covering the whole $6,018 \mathrm{~km}^{2}$ study area, as this cell size 
Post-print version. The final version of this article can be found at: Ameztegui A, Brotons L, Coll L. (2010) Land-use changes as major drivers of Mountain pine (Pinus uncinata Ram.) expansion in the Pyrenees. Global Ecology and Biogeography 19 (5): 632-641. DOI: $10.1111 / \mathrm{j} .1466-8238.2010 .00550 . x$

1 (2,25 ha) matches the minimum area considered in the Map of Habitats of Catalonia (MHCat)

2 (Icc, 2004). For each cell of the sampling grid, canopy cover in 1956 and 2006 were determined

3 as the ratio between the amount of 'tree' pixels and the total number of pixels in the cell,

4 expressed as percentage. A threshold of $10 \%$ canopy cover was used to distinguish 'forested'

5 from 'not-forested' cells. This threshold is also used in the Spanish National Forest Inventory

6 (Direccion General Para La Biodiversidad, 2007).

7 PLEASE INSERT HERE FIGURE 2

$8 \quad$ Dependent variables

$9 \quad$ Encroachment (Colonization)

10 Current distribution of Mountain pine (Mp06) was obtained by intersecting the sampling grid

11 with the MHCat, while distribution of Mountain pine in 1956 (Mp56) was obtained by

12 removing those sampling-grid cells qualified as 'not forested' in 1956. Encroachment was

13 assessed by establishing a 200 meters buffer around each Mp56 patch, as seed dispersion is

14 unlikely to occur beyond this distance (Dullinger et al., 2004). All land-cover types where

15 encroachment was not possible (e.g. lakes, rivers, reforested and stony areas) were excluded

16 from the analysis. Encroachment was then assessed using a binary approach. To minimize

17 sampling errors associated to the use of aerial photographs, we only defined as encroached those

18 cells with no tree cover in 1956 (i.e. tree cover $=0$ ) and with more than a $10 \%$ increase in

19 canopy cover in the studied period (Fig. 2). Deforestation processes (areas covered by Mountain

20 pine in 1956 but not in 2006) were not taken into account, as clear-cuts and deforestation are

21 scarce, with shelterwood, group and selection systems being the only treatments applied on

22 Mountain pine forests since the early 20th century (Gonzalez, 2008). 
Post-print version. The final version of this article can be found at: Ameztegui A, Brotons L, Coll L. (2010) Land-use changes as major drivers of Mountain pine (Pinus uncinata Ram.) expansion in the Pyrenees. Global Ecology and Biogeography 19 (5): 632-641. DOI: $10.1111 / \mathrm{j} .1466-8238.2010 .00550 . x$

1

2

\section{Densification}

Forest canopy cover can increase due to growth of pre-existent individuals as well as recruitment of new ones (densification). Our focus was on densification, so in order to separate these two processes, only those cells with a 1956 canopy cover of between $10 \%$ and $40 \%$ were considered in the analysis. Cells with a canopy cover lower than $10 \%$ were considered as 'not forested' and therefore not susceptible to undergo densification processes. Areas with canopy cover greater than $40 \%$ were also excluded on the basis that recruitment was impossible. In fact,

a Mountain pine stand with a canopy cover of $40 \%$ corresponds to an average density of 600

trees $\cdot \mathrm{ha}^{-1}$, which is the recommended threshold to start selection thinning (Gonzalez, 2008) and therefore wholly unsuitable for recruitment of new individuals. Furthermore, as a conservative measure aimed at assuring that only recruitment processes were taken into account, only areas showing more than a $30 \%$ increase in canopy cover were considered as densified due to recruitment (Fig. 2).

\section{Potential factors driving land-use changes}

A set of topographic and land-use variables were selected as potential drivers of Mountain pine encroachment and densification. The topographic variables included altitude, slope and aspect.

These three variables were obtained from a Digital Elevation Model (DEM) with a resolution of 150 meters, as expansion was assessed on a 150x150 m grid. Aspect was pre-transformed into a shade index to more adequately reflect variation between north and south aspects (Table 1). Thus, shade index increased from $0^{\circ}$ at south aspects to $180^{\circ}$ at north aspects, with east and west aspects given a value of $90^{\circ}$.

Land-use changes have affected forest expansion by two main processes: land abandonment and reduction of livestock density (Lasanta, 2002). However, these processes cannot be directly determined, as there is no local-level information on farmland extension or livestock densities 
Post-print version. The final version of this article can be found at: Ameztegui A, Brotons L, Coll L. (2010) Land-use changes as major drivers of Mountain pine (Pinus uncinata Ram.) expansion in the Pyrenees. Global Ecology and Biogeography 19 (5): 632-641. DOI: $10.1111 / \mathrm{j} .1466-8238.2010 .00550 . x$

1 for 1956. Indirect measures or proxies based on current available indicators provide an

2 alternative approach. Farmland abandonment during the second half of the 20th century is

3 strongly tied to depopulation and to changes in economic structure (Lasanta, 2002). Therefore,

4 the variable population change, defined as the ratio between population in 2001 and population

5 in 1951, was included in the models. In addition, population density, defined as the total

6 population in 2001 in relation the municipality's surface area in square kilometers; and importance of primary sector, defined as the proportion of primary-sector-dedicated employees (agriculture and stockbreeding) were used to assess differences in economic structure among municipalities (Table 1). As mentioned above, current livestock density is also a determinant of forest expansion. Garcia-Ruiz \& Lasanta (1990) observed that, at municipality level, livestock density was highly correlated with the extension of both subalpine pastures and lowland meadows. Therefore, influence of current livestock density on forest expansion was assessed by incorporating proportion of meadows and proportion of pastures for each municipality into the models (Table 1).

\section{PLEASE INSERT HERE TABLE 1}

\section{Statistical analyses}

As both response variables (encroachment and densification) were represented using a binary approach, they were modeled by logistic regression. This kind of model has been extensively used to assess land-cover changes, as they are commonly expressed as discrete variables (Carmel et al., 2001; Serneels \& Lambin, 2001; Munroe et al., 2004). Since logistic regression is based on the assumption of independence among observations, spatial autocorrelation for both response variables was tested using Moran's $I$ statistic. Since both response variables showed high autocorrelation, regular subsampling tools were applied. Subsampling is based on a sample-size reduction that causes distance between observations to increase, so only spatially- 
Post-print version. The final version of this article can be found at:

Ameztegui A, Brotons L, Coll L. (2010) Land-use changes as major drivers of Mountain pine (Pinus uncinata Ram.) expansion in the Pyrenees. Global Ecology and Biogeography 19 (5): 632-641.

DOI: $10.1111 / \mathrm{j} .1466-8238.2010 .00550 . x$

1 independent data are analyzed (Munroe et al., 2004). Semivariograms were constructed, and the

2 range (the distance after which semivariance stabilizes) was determined as approximately $400 \mathrm{~m}$

3 for both datasets. Therefore, as the sample grid was $150 \times 150 \mathrm{~m}$, only one of each three points in

4 both the $x$ and $y$ axis was sampled.

5 Given that most socio-economic variables were taken at municipality level and that these factors

6 may have an influence on both response variables, observations belonging to the same

7 municipality may not be independent from one another (cluster-correlated data), so we followed

8 the recommendations of Muller \& Munroe (2005) and used a robust estimator based on the

9 Huber-White or ‘sandwich’ estimator (Williams, 2000). 
Post-print version. The final version of this article can be found at:

Ameztegui A, Brotons L, Coll L. (2010) Land-use changes as major drivers of Mountain pine (Pinus uncinata Ram.) expansion in the Pyrenees. Global Ecology and Biogeography 19 (5): 632-641.

DOI: $10.1111 / \mathrm{j} .1466-8238.2010 .00550 . x$

1 Low levels of collinearity were found among the covariates. The coefficients of determination

$2\left(\mathrm{R}^{2}\right)$ of one variable against all the others ranged from 0.02 to 0.59 , which are in all cases below

3 the critical value of 0.80 set by Menard (2002). All independent variables were therefore used in

4 the models. Evidence of non-linearity between the independents and the logit of the dependent

5 were not found for any of the models, and thus variable transformation was not required.

6 In order to get the most parsimonious models, a stepwise procedure was performed to remove

7 non significant variables. Significance of covariates was tested using Wald statistic, and odds-

8 ratios for each covariate were estimated. Model accuracy was tested by Nagelkerke's $\mathrm{R}^{2}$ and

9 area under the receiver operating characteristic (ROC curve). The area under the ROC curve

10 (AUC) gives the probability that the model will properly distinguish between presence and

11 absence of the studied process, so predictions by chance would correspond to a value of

12 approximately 0.5 (Gellrich et al., 2007a). 
Post-print version. The final version of this article can be found at: Ameztegui A, Brotons L, Coll L. (2010) Land-use changes as major drivers of Mountain pine (Pinus uncinata Ram.) expansion in the Pyrenees. Global Ecology and Biogeography 19 (5): 632-641. DOI: $10.1111 / \mathrm{j} .1466-8238.2010 .00550 . x$

\section{RESULTS}

\section{Changes in Mountain pine forests}

3 In 1956, Mountain pine covered 55,196 ha, with an average canopy cover of 54.3\%. By 2006, it 4 had colonized 8,898 new hectares to reach a total of 64,074 ha, i.e. a $16.1 \%$ increase in surface

5 area. Mean canopy cover in 2006 had reached $60.9 \%$. However, to assess this process correctly,

6 changes in canopy cover should only be considered for the areas susceptible to densification

7 (canopy cover lower than $40 \%$ but higher than $10 \%$ in 1956, see methods for further detail).

8 Taking this into account, mean canopy cover in 1956 was $31.0 \%$, and by 2006 it has increased

9 up to 55.6\%, so canopy cover almost doubled in open Mountain pine forests between 1956 and 102006.

Variables driving Mountain pine encroachment and densification

Both logistic models for encroachment and densification were significant $(\mathrm{p}<0.001)$. However, their overall explanatory power was considerably low, as indicated by Nagelkerke's pseudo- $\mathrm{R}^{2}$, with values of 0.123 for the encroachment model and 0.101 for the densification model, while AUC was 0.699 for the encroachment model and 0.656 for the densification model.

The variable altitude contributed significantly $(\mathrm{p}<0.05)$ to both response variables, and the relationship was in both cases negative (Table 2), with forest expansion (i.e. encroachment or densification) more likely to occur at low altitudes. The odds of finding forest expansion were 2.7 times higher at 1500 meters than at 2500 meters, near the tree line. Therefore, the probability of forest encroachment varied from 0.50 at 1500 meters to 0.27 at 2300 meters, while the probability of densification varied between 0.80 and 0.60 for the same altitude range (Fig. 3). Shade index also contributed significantly and positively to both the encroachment and densification models ( $\mathrm{p}<0.05$; Table 2$)$. Thus, these processes were more likely to occur on 
Post-print version. The final version of this article can be found at: Ameztegui A, Brotons L, Coll L. (2010) Land-use changes as major drivers of Mountain pine (Pinus uncinata Ram.) expansion in the Pyrenees. Global Ecology and Biogeography 19 (5): 632-641. DOI: $10.1111 / \mathrm{j} .1466-8238.2010 .00550 . x$

1 northern rather than southern slopes. Odds-ratio was 1.010 and 1.011 for encroachment and

2 densification, respectively. This means that the odds of finding forest encroachment or

3 densification were nearly 6 times higher on northern slopes (shade index of 180) than on southern slopes (shade index of 0 ). Probability of encroachment therefore varied between 0.24 on south-facing slopes and 0.65 on northern aspects, while probability of densification varied between 0.55 and 0.90 for the same cases (Fig. 3). On the contrary, slope had no significant relationship with the response variable neither for the encroachment nor densification models (data not shown).

PLEASE INSERT HERE TABLE 2

None of the socio-economic variables showed significant relationships at $\mathrm{p}<0.05$ with the densification response variable (data not shown), meaning that either densification occurs independently of socio-economic conditions or that our proxy variables were unable to capture the ultimate driving factors for densification. However, the case was different for the encroachment model, in which population change and population density appeared to be significantly related to the observed changes in Mountain pine forests $(\mathrm{p}<0.05)$ while importance of primary sector, proportion of pastures and proportion of meadows were not (Table 2). The relationship between population change and encroachment was negative, showing that forests were more likely to encroach in municipalities with declining populations. For example, probability of encroachment was 0.45 for a municipality experiencing a $50 \%$ drop in population, but only 0.25 for a municipality doubling its population (Fig. 3). On the other hand, population density had a significant and positive relationship with changes in forest cover $(\mathrm{p}<0.05$; Table 2), thus encroachment was more likely to occur in municipalities with higher population density. The odds of finding encroachment in dense-populated municipalities (200 inhabitants per hectare) were 4.6 times higher than for a municipality with only 10 inhabitants 
Post-print version. The final version of this article can be found at: Ameztegui A, Brotons L, Coll L. (2010) Land-use changes as major drivers of Mountain pine (Pinus uncinata Ram.) expansion in the Pyrenees. Global Ecology and Biogeography 19 (5): 632-641. DOI: $10.1111 / \mathrm{j} .1466-8238.2010 .00550 . x$

1 per hectare, and probabilities of encroachment varied, for the same cases, from 0.74 to 0.38

2 (Fig. 3). On the other hand, no significant relationship was found between encroachment and the 3 proxies for the reduction of livestock density (data not shown). PLEASE INSERT HERE FIGURE 3

5

6 During the last half of the 20th century, there has been a significant expansion of Mountain pine

7 forests in the Eastern Pyrenees. This process has not occurred in a homogeneous way, and has

8 been strong in the low, north-facing slopes, although there is also a significant influence of

9 some of the socio-economic indicators.

The major influence of topographic variables on encroachment processes seems to indicate an effect of site conditions in Mountain pine expansion. The greatest probabilities of encroachment corresponded to low altitudes and to north-facing aspects, where neither thermal nor hydric limitations could condition the development of Mountain pine (Thuiller et al., 2003; Camarero \& Gutierrez, 2004; Batllori \& Gutierrez, 2008). Other studies conducted in Mountain areas (Poyatos et al., 2003; Coop \& Givnish, 2007; Lasanta \& Vicente-Serrano, 2007) have also reported lower encroachment rates in south-facing slopes associated with water stress. However, to correctly assess the importance and meaning of topographic variables, it is important to understand that they are not independent of patterns of land abandonment and livestock grazing in the Pyrenees, and therefore these results have to be reframed in a context of land-use changes (Poyatos et al., 2003). In the mid-19th century, when the population of the Pyrenees was at its peak, farmlands spread into hillslopes, occupying higher altitudes and slopes. Garcia-Ruiz (1988) points out that farmlands came to cover up to $30 \%$ of all land below 1600 meters. However, profitability limitations meant that cultivation only rarely rose above these altitudes. 
Post-print version. The final version of this article can be found at: Ameztegui A, Brotons L, Coll L. (2010) Land-use changes as major drivers of Mountain pine (Pinus uncinata Ram.) expansion in the Pyrenees. Global Ecology and Biogeography 19 (5): 632-641. DOI: $10.1111 / \mathrm{j} .1466-8238.2010 .00550 . x$

1 Along with the important changes on land-organisation during the 20th century, agriculture

concentrated in the valley-bottoms, leaving most hillslopes abandoned, especially those situated on higher altitudes (Poyatos et al., 2003). Since only $10 \%$ of the Mountain pine stands are located on altitudes below $1,600 \mathrm{~m}$, areas with higher abandon rate would correspond to the lowest altitudes in the study area. Aspect is also not independent of land abandonment patterns, since farmlands were primarily located on south-facing slopes, with better conditions for cultivation. Therefore, after the maximum expansion of farmlands, those located on northfacing aspects were the first to be abandoned. Furthermore, the south-facing slopes had been cultivated for thousands of years, causing a loss of fertility that could limit or delay forest encroachment especially in highest and steepest areas, where no soil conservation techniques or fertilization were implemented (Garcia-Ruiz, 1988; Garcia-Ruiz et al., 1996; Lasanta \& Vicente-Serrano, 2007). Patterns of livestock grazing are also related to topographic variables, especially altitude. When transhumance was still practiced, livestock grazed subalpine grasslands during the summer and moved to the Ebro valley in the winter (Garcia-Ruiz et al., 1996; Domínguez, 2001), while low and mid-range forests and scrublands were grazed in the intermediate periods, accounting for $17 \%$ of the total livestock food sources in Central Pyrenees (Garcia-Ruiz et al., 1996; Lasanta, 2002). More recent farming practices only use summer grasslands, while autumn, winter and spring food is obtained from lowland meadows, and forest and scrublands only account for $2 \%$ of the total food supply (Domínguez, 2001). Therefore, there has been a significant reduction in livestock density on low and mid-range land, which have almost disappeared as grazing areas, while grazing in subalpine summer pastures, although at lower livestock density, remains important.

Mountain pine encroachment was also significantly affected by patterns of farmland abandonment on the municipality level, as indicated by its relationship with the analyzed proxies. However, it was not the case for proxies of livestock density. Probability of 
Post-print version. The final version of this article can be found at: Ameztegui A, Brotons L, Coll L. (2010) Land-use changes as major drivers of Mountain pine (Pinus uncinata Ram.) expansion in the Pyrenees. Global Ecology and Biogeography 19 (5): 632-641. DOI: $10.1111 / \mathrm{j} .1466-8238.2010 .00550 . x$

1 encroachment was higher in municipalities experiencing greater population losses and in

2 municipalities with higher population density. These findings reflect two extreme cases of

3 changes in population structure in the Pyrenees. On one hand, small villages, where the economy was highly dependent on agriculture and stockbreeding, suffered strong depopulation over the 20th century, as traditional activities lost profitability (Molina, 2002; Gellrich et al., 2008). In these municipalities, rate of land abandonment (and associated forest encroachment) is highly related to depopulation (Lasanta, 1990). On the other hand, the biggest villages had developed a trade and industry network, so instead of losing population they actually recruited part of the exodus from the smaller villages (Lasanta, 1990; Molina, 2002). Furthermore, the 1970s marked the growth of tourism as an important economic sector in the Pyrenees. Most of the tourist facilities were located in the most populated villages in each valley, where tourists could find the services they demanded (Molina, 2002), further consolidating the population differences between small and big villages. However, in these municipalities, a greater population density does not necessarily correspond to a greater pressure on the territory, as their economy is not based on primary sectors. In fact, most of the tourist facilities (apartments, camp sites and hotels) were sited on valley-bottoms, where they directly compete for space with meadows and farmlands, causing opportunity costs for agriculture and stockbreeding to increase, and therefore contributing to land abandonment. Lasanta (2002) found a positive and significant correlation between tourist development and rates of farmland abandonment and livestock density decline in several municipalities in the Pyrenees, while other authors report correlations between high population densities and rates of forest encroachment (Gellrich et al., 2007a; Gellrich et al., 2008). Surprisingly, the variable primary sector showed a non-significant relationship with encroachment probability. This is likely related to the increasing number of part-time farms (i.e. where the farmer is not exclusively dedicated to agriculture or stockbreeding) established in the area over the last few decades. Gellrich et al. (2007a) 
Post-print version. The final version of this article can be found at:

Ameztegui A, Brotons L, Coll L. (2010) Land-use changes as major drivers of Mountain pine (Pinus uncinata Ram.) expansion in the Pyrenees. Global Ecology and Biogeography 19 (5): 632-641. DOI: $10.1111 / \mathrm{j} .1466-8238.2010 .00550 . x$

1 highlighted the importance of part-time farms in determining forest encroachment in the Alps.

2 Therefore, the lack of significance for primary sector activity could be due to these part-time

3 farmers, who are not included in the agrarian census.

4 Unlike encroachment, densification was not significantly influenced by any of the socio-

5 economic covariates. According to Poyatos et al. (2003), forest densification reflects the

6 decreasing use of fuelwood and timber as a result of population decline and the shift towards

7 other energy sources and materials. However, Mountain pine timber has never been extensively

8 used as fuelwood in the Pyrenees, where other species, such as beech or oak, were preferred due

9 to their better properties and proximity to village centres. Nevertheless, densification is

10 significantly related to altitude and, above all, to aspect. This could imply that climatic

11 conditions may limit this process, either by temperature constraints at higher altitudes or by

12 drought conditions on south-facing slopes. In any case, our analysis of Mountain pine

densification focuses exclusively on the period 1956-2006. However, land abandonment, and

hence forest encroachment, has started before 1956. Indeed, Lasanta (2002) points out that most of the non-permanent and low-fertility farmlands had already been abandoned by 1936 . Thus, many of these areas could have undergone encroachment processes in the following years and therefore, by 1956, would present low canopy cover susceptible to densificate in the following years. Hence, patterns of densification may depend on encroachment patterns prior to 1956. Our results agree with this premise since densification processes were found to be more important in north-facing exposures and low altitudes (between 1200-1600 m) home to the first farmlands to be abandoned during the first half of the century (Garcia-Ruiz, 1988; Poyatos et al., 2003). to patterns of farmland abandonment. Forest has colonized most of the abandoned fields, and 
Post-print version. The final version of this article can be found at:

Ameztegui A, Brotons L, Coll L. (2010) Land-use changes as major drivers of Mountain pine (Pinus uncinata Ram.) expansion in the Pyrenees. Global Ecology and Biogeography 19 (5): 632-641.

DOI: $10.1111 / \mathrm{j} .1466-8238.2010 .00550 . x$

1 therefore forest encroachment has been more important at low and medium altitudes than close

2 to the tree line, indicating that land-use changes have a greater influence on forest expansion

3 than climate changes. However, this does not mean climate has no influence on forest dynamics,

4 as the response of forest-grassland ecotones to climate changes depends on several factors,

5 including autoecological characteristics, phenotypic plasticity and availability of regeneration

6 niches, among others (Camarero \& Gutierrez, 1999; Holtmeier \& Broll, 2005). Therefore,

7 influence of climate change is not necessarily reflected as tree line displacements, as changes in

8 stand density and recruitment or in growth form are more likely to occur (Szeicz \& Macdonald,

9 1995; Camarero et al., 2000; Camarero \& Gutierrez, 2004; Gehrig-Fasel et al., 2007; Batllori \&

10 Gutierrez, 2008). In fact, Camarero \& Gutierrez $(1999 ; 2004)$ studying a Mountain pine stand in

11 the Pyrenees, found significant changes in recruitment and tree growth inside the stand, despite

12 a reduced or even null altitudinal rise of the tree line. However, even considering the influence

13 of climate on tree line dynamics, our results indicate that, in the Pyrenees, land-use changes are

14 the main drivers of recent Mountain pine encroachment at regional scale. Therefore, future

15 research on tree line dynamics in the Pyrenees should explicitly consider the influence of land-

16 use changes in order to correctly estimate the net contribution of climate-change associated

17 processes. 
Post-print version. The final version of this article can be found at:

Ameztegui A, Brotons L, Coll L. (2010) Land-use changes as major drivers of Mountain pine (Pinus uncinata Ram.) expansion in the Pyrenees. Global Ecology and Biogeography 19 (5): 632-641.

DOI: $10.1111 / \mathrm{j} .1466-8238.2010 .00550 . \mathrm{x}$

\section{ACKNOWLEDGEMENTS}

2 This research was primarily supported by the Spanish Ministry of Science and Innovation via

3 the Consolider-Ingenio Montes project (CSD2008-00040) and the DINAMIX project

4 (AGL2009-13270-C02). It was also supported by a Ramon y Cajal contract to Drs. L.Coll and

5 L.Brotons, and a doctoral grant to the first author (AP2007-01663). Additional funding came

6 from the Departament de Medi Ambient of the Regional Catalan government. The authors thank

7 the Department of Geography of the Universitat Autònoma de Barcelona for kindly providing

8 access to aerial photographs, and Dr. Gonzalez-Olabarria for valuable input on drafting the

9 manuscript. 
Post-print version. The final version of this article can be found at:

Ameztegui A, Brotons L, Coll L. (2010) Land-use changes as major drivers of Mountain pine (Pinus uncinata Ram.) expansion in the Pyrenees. Global Ecology and Biogeography 19 (5): 632-641.

DOI: 10.1111/j.1466-8238.2010.00550.x

\section{REFERENCES}

Batllori, E. \& Gutierrez, E. (2008) Regional tree line dynamics in response to global change in the Pyrenees. Journal of Ecology, 96, 1275-1288.

Bucher, A. \& Dessens, J. (1991) Secular trend of surface-temperature at an elevated observatory in the Pyrenees. Journal of Climate, 4, 859-868.

Camarero, J. J. \& Gutierrez, E. (1999) Structure and recent recruitment at alpine forest-pasture ecotones in the Spanish central Pyrenees. Ecoscience, 6, 451-464.

Camarero, J. J. \& Gutierrez, E. (2004) Pace and pattern of recent treeline dynamics: Response of ecotones to climatic variability in the Spanish Pyrenees. Climatic Change, 63, 181200.

Camarero, J. J. \& Gutierrez, E. (2007) Response of Pinus uncinata recruitment to climate warming and changes in grazing pressure in an isolated population of the Iberian system (NE Spain). Arctic Antarctic and Alpine Research, 39, 210-217.

Camarero, J. J., Gutierrez, E. \& Fortin, M. J. (2000) Spatial pattern of subalpine forest-alpine grassland ecotones in the Spanish Central Pyrenees. Forest Ecology and Management, 134, 1-16.

Camarero, J. J., Gutierrez, E. \& Fortin, M. J. (2006) Spatial patterns of plant richness across treeline ecotones in the Pyrenees reveal different locations for richness and tree cover boundaries. Global Ecology and Biogeography, 15, 182-191.

Carmel, Y., Kadmon, R. \& Nirel, R. (2001) Spatiotemporal predictive models of Mediterranean vegetation dynamics. Ecological Applications, 11, 268-280.

Coop, J. D. \& Givnish, T. J. (2007) Spatial and temporal patterns of recent forest encroachment in montane grasslands of the Valles Caldera, New Mexico, USA. Journal of Biogeography, 34, 914-927.

Chauchard, S., Carcaillet, C. \& Guibal, F. (2007) Patterns of land-use abandonment control tree-recruitment and forest dynamics in Mediterranean mountains. Ecosystems, 10, 936948.

Dale, V. H. (1997) The relationship between land-use change and climate change. Ecological Applications, 7, 753-769.

Debussche, M., Lepart, J. \& Dervieux, A. (1999) Mediterranean landscape changes: evidence from old postcards. Global Ecology and Biogeography, 8, 3-15.

Diaz, H. F. \& Bradley, R. S. (1997) Temperature variations during the last century at high elevation sites. Climatic Change, 36, 253-279.

Direccion General Para La Biodiversidad. (2007) Tercer Inventario Forestal Nacional (19972007), edn. Ministerio de Medio Ambiente, Madrid.

Dirnböck, T., Dullinger, S. \& Grabherr, G. (2003) A regional impact assessment of climate and land-use change on alpine vegetation. Journal of Biogeography, 30, 401-417.

Domínguez, R. (2001) Las transformaciones del sector ganadero en España (1940-1985). Ager, $1,47-84$. 
Post-print version. The final version of this article can be found at:

Ameztegui A, Brotons L, Coll L. (2010) Land-use changes as major drivers of Mountain pine (Pinus uncinata Ram.) expansion in the Pyrenees. Global Ecology and Biogeography 19 (5): 632-641.

DOI: 10.1111/j.1466-8238.2010.00550.x

Dullinger, S., Dirnbock, T. \& Grabherr, G. (2004) Modelling climate change-driven treeline shifts: relative effects of temperature increase, dispersal and invasibility. Journal of Ecology, 92, 241-252.

Garcia-Ruiz, J. M. (1988) La evolución de la agricultura de montaña y sus efectos sobre la dinámica del paisaje. Revista de Estudios Agro-Sociales, 146, 7-37.

Garcia-Ruiz, J. M. \& Lasanta, T. (1990) Land-use changes in the Spanish Pyrenees. Mountain Research and Development, 10, 267-279.

Garcia-Ruiz, J. M., Lasanta, T., Ruiz-Flaño, P., Ortigosa, L., White, S., Gonzalez, C. \& Marti, C. (1996) Land-use changes and sustainable development in mountain areas: A case study in the Spanish Pyrenees. Landscape Ecology, 11, 267-277.

Gehrig-Fasel, J., Guisan, A. \& Zimmermann, N. E. (2007) Tree line shifts in the Swiss Alps: Climate change or land abandonment? Journal of Vegetation Science, 18, 571-582.

Gellrich, M., Baur, P., Koch, B. \& Zimmermann, N. E. (2007a) Agricultural land abandonment and natural forest re-growth in the Swiss mountains: A spatially explicit economic analysis. Agriculture Ecosystems \& Environment, 118, 93-108.

Gellrich, M., Baur, P., Robinson, B. H. \& Bebi, P. (2008) Combining classification tree analyses with interviews to study why sub-alpine grasslands sometimes revert to forest: A case study from the Swiss Alps. Agricultural Systems, 96, 124-138.

Gellrich, M., Baur, P. \& Zimmermann, N. E. (2007b) Natural forest regrowth as a proxy variable for agricultural land abandonment in the Swiss mountains: a spatial statistical model based on geophysical and socio-economic variables. Environmental Modeling \& Assessment, 12, 269-278.

Gellrich, M. \& Zimmermann, N. E. (2007) Investigating the regional-scale pattern of agricultural land abandonment in the Swiss mountains: A spatial statistical modelling approach. Landscape and Urban Planning, 79, 65-76.

Gonzalez, J. M. (2008) Selvicultura de Pinus uncinata. Compendio de selvicultura aplicada en España (ed. by R. Serrada \& G. Montero \& J.A. Reque), pp 535-546. Instituto Nacional de Investigación y Tecnología Agraria y Alimentaria - Ministerio de Educación y Ciencia, Madrid.

Hofgaard, A. (1997) Inter-relationships between treeline position, species diversity, land use and climate change in the central Scandes Mountains of Norway. Global Ecology and Biogeography, 6, 419-429.

Holtmeier, F. K. \& Broll, G. (2005) Sensitivity and response of northern hemisphere altitudinal and polar treelines to environmental change at landscape and local scales. Global Ecology and Biogeography, 14, 395-410.

Icc. (2004) Mapa d'Hàbitats de Catalunya. Institut Cartogràfic de Catalunya. Generalitat de Catalunya.

Jump, A. S., Hunt, J. M. \& Penuelas, J. (2006) Rapid climate change-related growth decline at the southern range edge of Fagus sylvatica. Global Change Biology, 12, 2163-2174.

Lasanta-Martinez, T., Vicente-Serrano, S. M. \& Cuadrat-Prats, J. M. (2005) Mountain Mediterranean landscape evolution caused by the abandonment of traditional primary activities: a study of the Spanish Central Pyrenees. Applied Geography, 25, 47-65. 
Post-print version. The final version of this article can be found at:

Ameztegui A, Brotons L, Coll L. (2010) Land-use changes as major drivers of Mountain pine (Pinus uncinata Ram.) expansion in the Pyrenees. Global Ecology and Biogeography 19 (5): 632-641.

DOI: 10.1111/j.1466-8238.2010.00550.x

Lasanta, T. (1990) Tendances actuelles de l'organisation spatiale des montagnes espagnoles. Annales de Géographie, 551, 51-71.

Lasanta, T. (2002) Los sistemas de gestión en el Pirineo central español durante el siglo XX: del aprovechamiento global de los recursos a la descoordinación espacial en los usos del suelo. Ager, 2, 173-196.

Lasanta, T. \& Vicente-Serrano, S. M. (2007) Cambios en la cubierta vegetal en el Pirineo aragonés en los últimos 50 años. Pirineos, 162, 125-154.

Macdonald, G. M., Szeicz, J. M., Claricoates, J. \& Dale, K. A. (1998) Response of the central Canadian treeline to recent climatic changes. Annals of the Association of American Geographers, 88, 183-208.

Menard, S. (2002) Applied Logistic Regression Analysis. Quantitative applications in the social sciences. $N^{o} 106$, edn. Sage, London.

Miller, M. E. (1999) Use of historic aerial photography to study vegetation change in the Negrito Creek watershed, southwestern New Mexico. Southwestern Naturalist, 44, 121137.

Millington, J. D. A., Perry, G. L. W. \& Romero-Calcerrada, R. (2007) Regression techniques for examining land use/cover change: A case study of a mediterranean landscape. Ecosystems, 10, 562-578.

Molina, D. (2002) El proceso de desertización demográfica de la montaña pirenaica en el largo plazo: Cataluña. Ager, 2, 81-100.

Muller, D. \& Munroe, D. K. (2005) Tradeoffs between rural development policies and forest protection: Spatially explicit modeling in the central highlands of Vietnam. Land Economics, 81, 412-425.

Munroe, D. K., Southworth, J. \& Tucker, C. M. (2004) Modeling spatially and temporally complex land-cover change: The case of western Honduras. Professional Geographer, 56, 544-559.

Peñuelas, J. \& Boada, M. (2003) A global change-induced biome shift in the Montseny mountains (NE Spain). Global Change Biology, 9, 131-140.

Poyatos, R., Latron, J. \& Llorens, P. (2003) Land use and land cover change after agricultural abandonment - The case of a Mediterranean Mountain Area (Catalan Pre-Pyrenees). Mountain Research and Development, 23, 362-368.

Rutherford, G. N., Bebi, P., Edwards, P. J. \& Zimmermann, N. E. (2008) Assessing land-use statistics to model land cover change in a mountainous landscape in the European Alps. Ecological Modelling, 212, 460-471.

Sala, O. E., Chapin Iii, F. S. \& Huber-Sannwald, E. (2001) Potential biodiversity change: global patterns and biome comparisons. Global biodiversity in a changing environment: scenarios for the 21 st century (ed. by F.S. Chapin Iii \& O.E. Sala \& E. HuberSannwald), pp 376. Springer-Verlag, New York.

Serneels, S. \& Lambin, E. F. (2001) Proximate causes of land-use change in Narok District, Kenya: a spatial statistical model. Agriculture Ecosystems \& Environment, 85, 65-81.

Szeicz, J. M. \& Macdonald, G. M. (1995) Recent white spruce dynamics at the sub-artic alpine treeline of North-Western Canada. Journal of Ecology, 83, 873-885. 
Post-print version. The final version of this article can be found at:

Ameztegui A, Brotons L, Coll L. (2010) Land-use changes as major drivers of Mountain pine (Pinus uncinata Ram.) expansion in the Pyrenees. Global Ecology and Biogeography 19 (5): 632-641.

DOI: 10.1111/j.1466-8238.2010.00550.x

Thuiller, W., Vayreda, J., Pino, J., Sabate, S., Lavorel, S. \& Gracia, C. (2003) Large-scale environmental correlates of forest tree distributions in Catalonia (NE Spain). Global Ecology and Biogeography, 12, 313-325.

Williams, R. L. (2000) A note on robust variance estimation for cluster-correlated data. Biometrics, 56, 645-646. 
Post-print version. The final version of this article can be found at:

Ameztegui A, Brotons L, Coll L. (2010) Land-use changes as major drivers of Mountain pine (Pinus uncinata Ram.) expansion in the Pyrenees. Global Ecology and Biogeography 19 (5): 632-641.

DOI: 10.1111/j.1466-8238.2010.00550.x

1 TABLES

Table 1 Covariates included in the model, indicating source, resolution and descriptive statistics

\begin{tabular}{|c|c|c|c|c|c|c|c|}
\hline Variable & Source & Resolution & Mean & Std. Dev. & Min. & Max. & Range \\
\hline \multicolumn{8}{|l|}{ Topographic } \\
\hline Altitude & DEM & $150 \mathrm{~m}$ & 1984.3 & 256.1 & 1340.2 & 2514.9 & 1174.7 \\
\hline Slope & DEM & $150 \mathrm{~m}$ & 44.5 & 20.5 & 0.0 & 146.0 & 146.0 \\
\hline Shade Index & DEM & $150 \mathrm{~m}$ & 70.2 & 45.2 & 0.0 & 180.0 & 180.0 \\
\hline \multicolumn{8}{|l|}{ Socio-economic } \\
\hline \multicolumn{8}{|c|}{ Proxies for farmland abandonment } \\
\hline Population change & INE & Municipality & 84.5 & 46.6 & 16.0 & 214.0 & 198.0 \\
\hline Population density & INE & Municipality & 7.7 & 17.5 & 0.7 & 371.0 & 370.3 \\
\hline Imp. Primary Sector & IDESCAT & Municipality & 13.9 & 8.9 & 0.0 & 53.0 & 53.0 \\
\hline \multicolumn{8}{|c|}{ Proxies for reduction of livestock density } \\
\hline$\%$ meadows & IDESCAT & Municipality & 1.7 & 3.5 & 0.0 & 29.7 & 28.0 \\
\hline$\%$ pastures & IDESCAT & Municipality & 42.4 & 18.4 & 2.4 & 80.2 & 77.8 \\
\hline
\end{tabular}

DEM: Digital elevation model; INE: Spanish National Statistics Institute; IDESCAT: Catalan

Statistics Institute 
Post-print version. The final version of this article can be found at:

Ameztegui A, Brotons L, Coll L. (2010) Land-use changes as major drivers of Mountain pine (Pinus uncinata Ram.) expansion in the Pyrenees. Global Ecology and Biogeography 19 (5): 632-641.

DOI: 10.1111/j.1466-8238.2010.00550.x

Table 2 List of main parameters of both encroachment and densification logistic models. Only variables included in the model after stepwise procedure are showed $(\mathrm{p}<0.05)$.

\begin{tabular}{lrrrr}
\hline Variable & Coefficient & Wald Statistic & p & Odds-Ratio \\
\hline Encroachment & & & & \\
$\quad$ Intercept & 1.173 & 13.92 & $<0.001$ & - \\
Altitude & -0.001 & 74.04 & $<0.001$ & 0.999 \\
Shade Index & 0.010 & 117.60 & $<0.001$ & 1.010 \\
$\quad$ Population change & -0.005 & 28.79 & $<0.001$ & 0.995 \\
Pop. Density & 0.008 & 22.32 & $<0.001$ & 1.008 \\
& & & & \\
Densification & & & & \\
$\quad$ Intercept & 2.170 & 4.50 & 0.038 & - \\
$\quad$ Altitude & -0.001 & 7.92 & 0.006 & 0.999 \\
Shade Index & 0.011 & 31.25 & $<0.001$ & 1.011 \\
\hline
\end{tabular}


Post-print version. The final version of this article can be found at:

Ameztegui A, Brotons L, Coll L. (2010) Land-use changes as major drivers of Mountain pine (Pinus uncinata Ram.) expansion in the Pyrenees. Global Ecology and Biogeography 19 (5): 632-641.

FIGURES

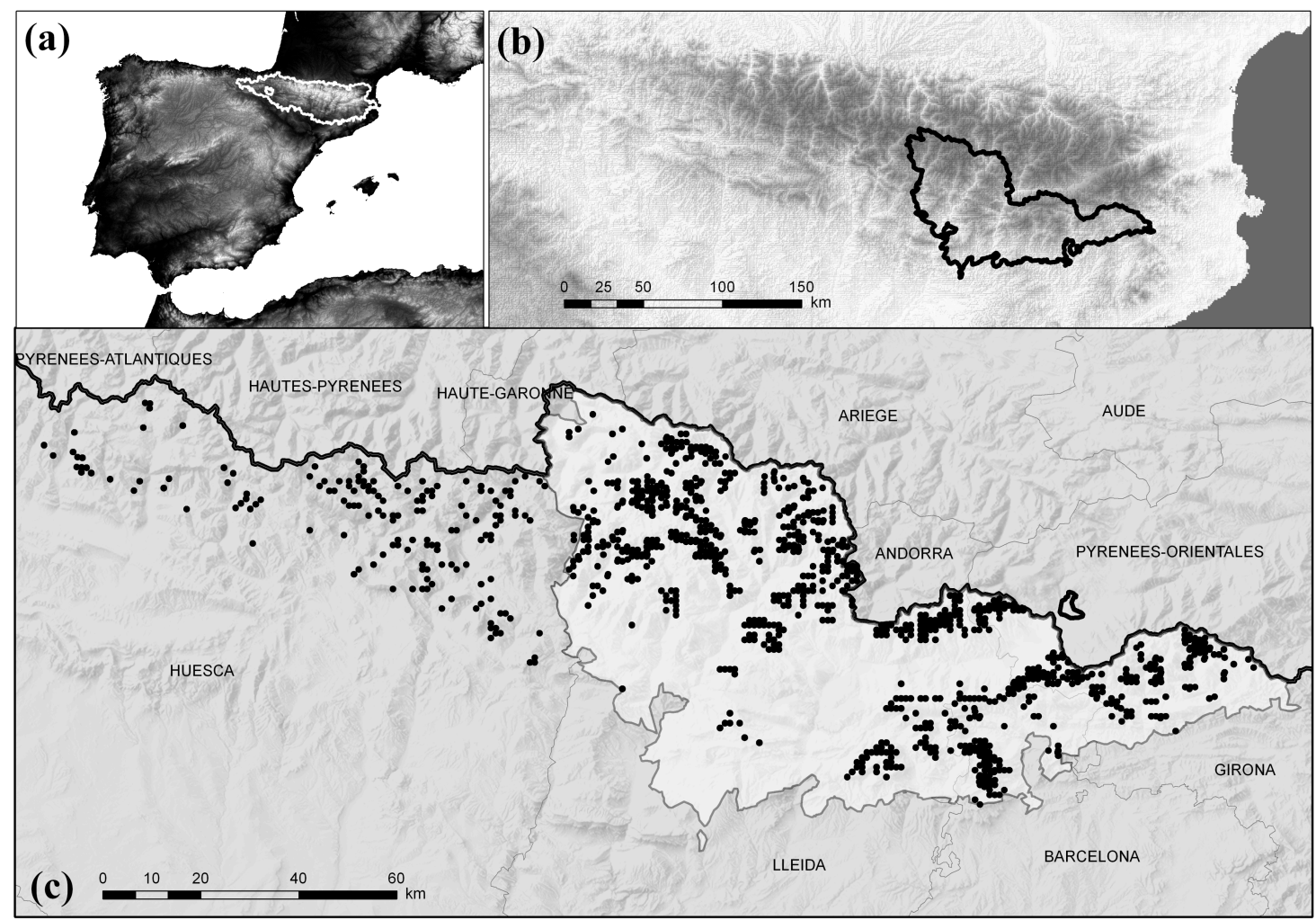

Figure 1 Location of study area showing (a) Pyrenees mountain range; (b) study area inside the Pyrenees; (c) current distribution of Mountain pine in Spanish Pyrenees and in study area (white shaded) according to Third National Forest Inventory (Direccion General Para La Biodiversidad, 2007). 
Post-print version. The final version of this article can be found at:

Ameztegui A, Brotons L, Coll L. (2010) Land-use changes as major drivers of Mountain pine (Pinus uncinata Ram.) expansion in the Pyrenees. Global Ecology and Biogeography 19 (5): 632-641.

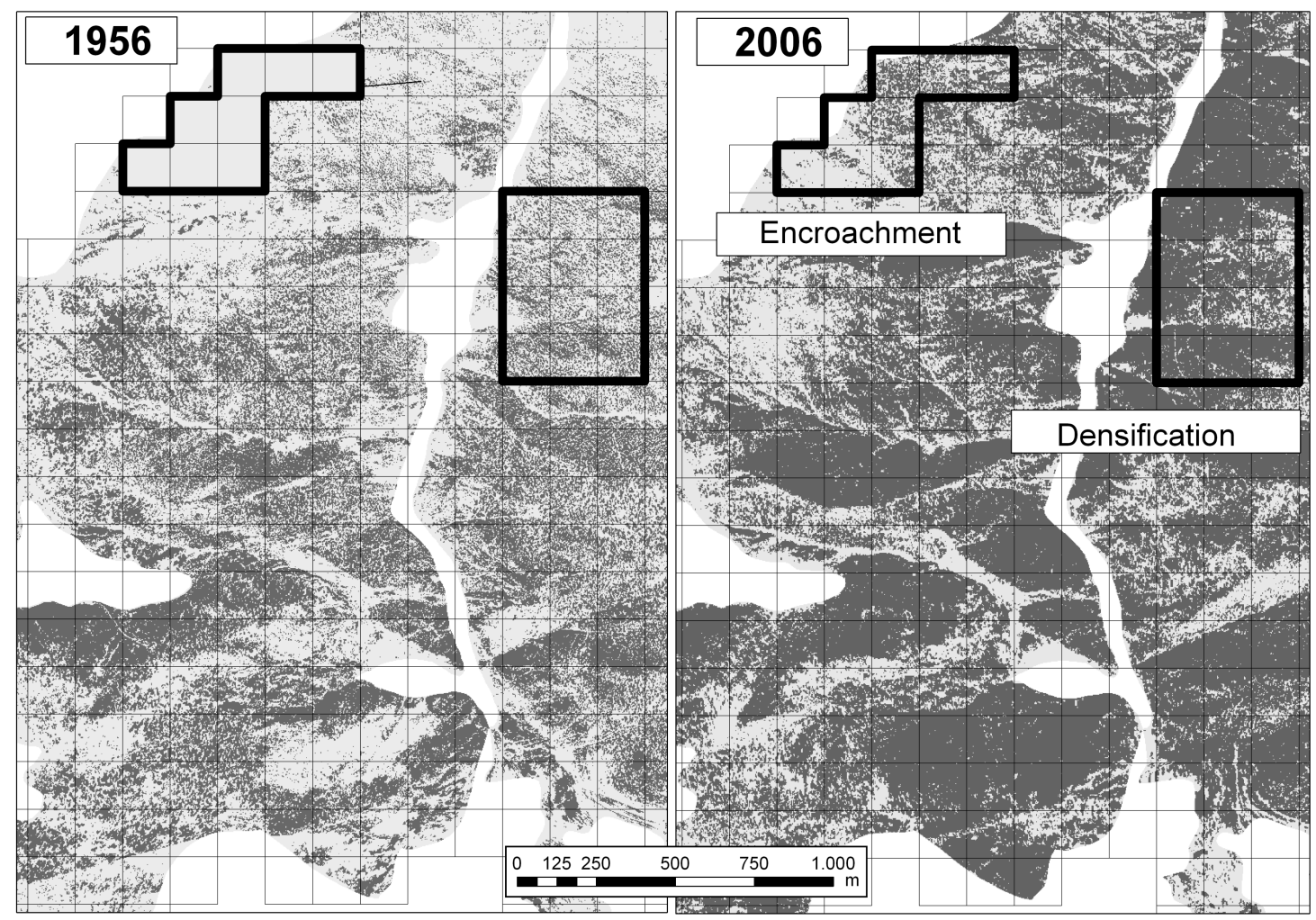

Figure 2 Example of 1956 (left) and 2006 (right) aerial photographs, reclassified into a binary variable to show Mountain pine distribution. Thin solid lines correspond to 150x150 m sampling grid, while thick solid lines correspond to examples of encroachment and densification processes. 
Post-print version. The final version of this article can be found at:

Ameztegui A, Brotons L, Coll L. (2010) Land-use changes as major drivers of Mountain pine (Pinus uncinata Ram.) expansion in the Pyrenees. Global Ecology and Biogeography 19 (5): 632-641.
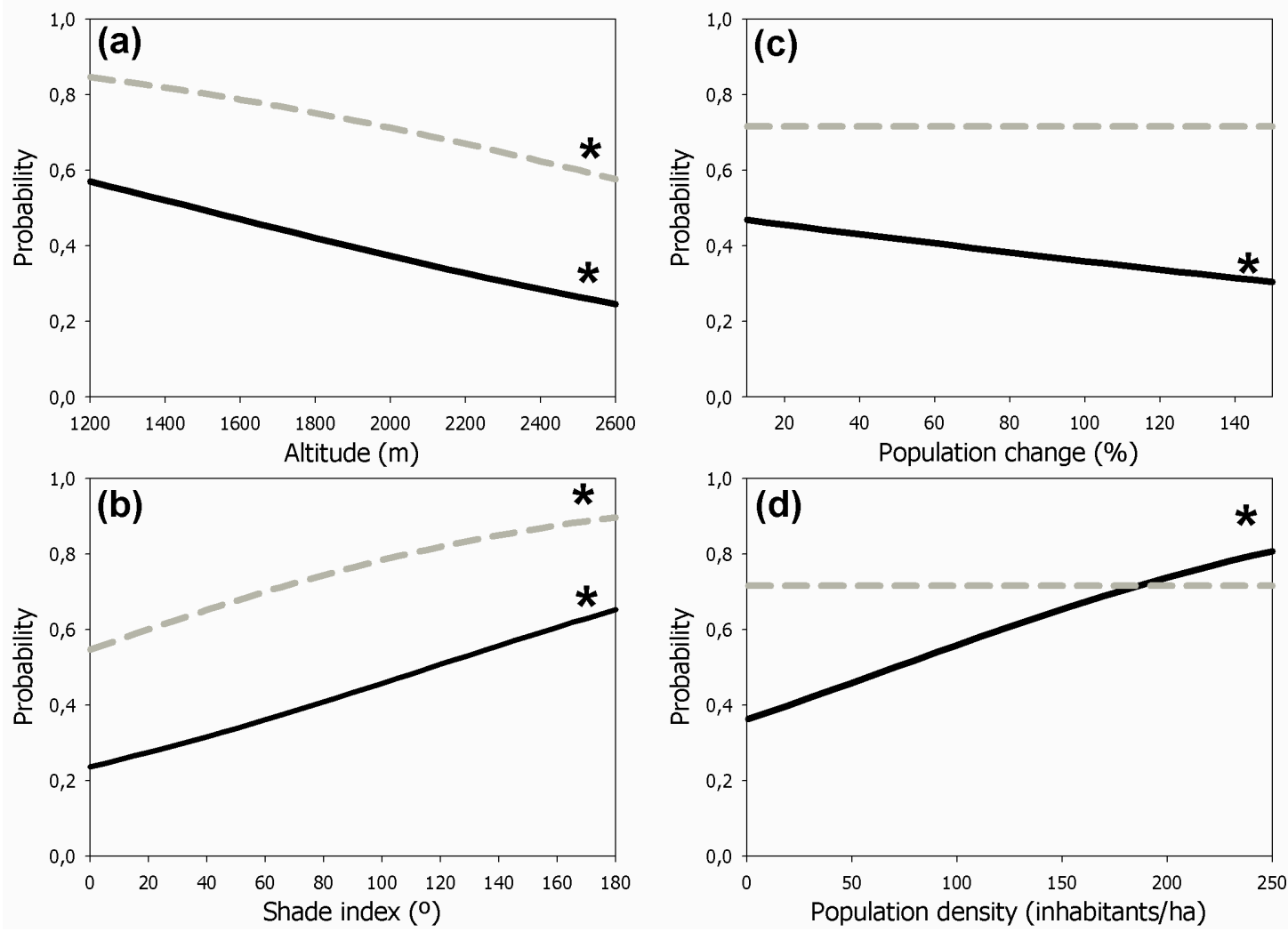

Figure 3 Effect of altitude (a), shade index (b) population change (c) and population density (d) (c) on the probability of encroachment (black solid line) and densification (grey dashed line), according to developed models (Table 2). Variables other than the one on the $x$ axis are equal to their mean value in the modeling data (Table 1). Significant relationships are indicated by an asterisk $(*)$ above the curve. 